\title{
Aszfaltburkolatú útpályaszerkezetek méretezése hőmérséklet profil alapján
}

\section{Seoyoung Cho ${ }^{1}$, Pethő László ${ }^{2}$, Tóth Csaba ${ }^{1}$, Lakatos Éva ${ }^{3}$}

${ }^{1}$ Budapesti Műszaki és Gazdaságtudományi Egyetem, Építőmérnöki Kar, Út és Vasútépítési Tanszék

${ }^{2}$ Fulton Hogan Infrastructure Services

${ }^{3}$ Budapesti Müszaki és Gazdaságtudományi Egyetem, Építőmérnöki Kar, Tartószerkezetek Mechanikája Tanszék

E-mail: hotaru128@hanmail.net, laszlo.petho@fultonhogan.com.au, toth.csaba@epito.bme.hu, lakatoseva@mail.bme.hu

DOI: $\underline{10.36246 / U L .2020 .2 .07}$

\section{KIVONAT}

A hajlékony útpályaszerkezetek viselkedésének tanulmányozásában, az aszfaltrétegek kötőanyagtartalmának köszönhetően a hőmérséklet hatása nagy jelentőséggel bír. A jelenlegi szakmai gyakorlat ezt a problémát az ún. ekvivalens hőmérséklet segítségével igyekszik kiküszöbölni, azaz rétegenként, olyan egyenértékű hőmérséklet és ennek eredményeként olyan aszfaltmodulus értékeket használ, amelyek, ha a teljes év alatt változatlanok lennének, akkor ugyanakkora fáradási kár keletkezne a pályaszerkezetben, mint a különböző hőmérsékletek eltérő aszfaltmodulusaival számolt igénybevételek összegzett hatása. Cikkünkben azt vizsgáljuk, ha egy ún. meteorológiai évet veszünk valós hőmérsékleti adatokkal, akkor a modellezett pályaszerkezet elméleti viselkedése hogyan alakul a hagyományos méretezési elvekkel számított eredményekhez képest.

Kulcsszavak: hőmérsékleti profil, hajlékony pályaszerkezet modellezés, végeselemmódszer

\section{ABSTRACT}

In the study of the behavior of flexible pavements, the effect of temperature is of great importance due to the binder content of the asphalt layers. The current professional practice tries to eliminate this problem with the help of the equivalent temperature. Therefore, such an equivalent temperature and as a result of it such an asphalt modulus values have been applied layer by layer and, which, if left unchanged throughout the year, would cause the same fatigue damage in the pavement as the sum of the loads calculated for different asphalt moduluses at different temperatures. In our article, we examine if we take a meteorological year with real temperature data, then how the theoretical behavior of the modeled pavement changes compared to the results, which calculated with traditional pavement design method.

Keywords: temperature profile, flexible pavement design, finite element method

\author{
Seoyoung Cho \\ A Budapesti Müszaki és Gazdaságtudományi Egyetem, Út és Vasútépitési Tanszék PhD hallgatója.
}

\section{Dr. Pethő László}

Pethö László regisztrált szakmérnök több mint 19 év nemzetközi tapasztalattal az aszfaltkeverék tervezés, minőségvizsgálat és pályaszerkezet méretezés területén. Jenleg a Fulton Hogan Infrastructure Services- 
nél pályaszerkezet szekértöként dolgozik, ahol többek között pályaszerkezetek teljesitményével és innovativ technológiák alkalmazásával foglalkozik.

\section{Dr. Tóth Csaba}

A Magyar Mérnöki Kamara, a Közlekedéstudományi Egyesület, a Magyar Útügyi Társaság Útpályaszerkezetek Szakbizottság tagja, jelenleg az BME Út és Vasútépitési Tanszék docense. Korábban a Csongrád Megyei Állami Közútkezelö Kht., illetve az Állami Közúti Müszaki és Információs Kht. osztályvezetöjeként a magyar útügyi adminisztrációban dolgozott. Késöbb a Strabag Konszern mérnökeként részt vett az épülö hazai országos közúthálózat minöségellenörzésében, valamint a Konszern nemzetközi és hazai kutatásaiban. Közlekedési épitömérnöki szakértöként, tervezöként, illetve müszaki ellenörként közremüködött számos hazai burkolat-megerösitési projektben. Kutatási területe: hajlékony útpályaszerkezetek igénybevétele, méretezése, teherbiró-képessége, megerősitése. Publikációinak száma: több mint 50.

\section{Dr. Lakatos Éva}

A Budapesti Müszaki és Gazdaságtudományi Egyetem (BME), Tartószerkezetek Mechanikája Tanszékének munkatársa. Fö kutatási területe a biomechanika - biológiai anyagok és implantátumok végeselemes vizsgálata, porózus szilárd anyagok szerkezeti és anizotrop tulajdonságai.

\section{AZ ASZFALTBURKOLAT FELÜLETI HŐMÉRSÉKLETÉNEK ÉVES ELOSZLÁSA}

Ha egy aszfaltburkolatú útpályaszerkezet különböző mélységeiben kialakuló hőmérsékletet szeretnénk megbecsülni, első lépésként célszerü a felületi hőmérsékletéből kiindulni, hiszen az közvetlenül is mérhető.

Aszfaltburkolaton mért hőmérsékleti eloszlás relatív gyakoriságát egy korábban létrehozott (Pethő, 2008) - több publikációban is szereplő - meteorológiai állomástól kapott hőmérsékleti adatgyüjtésből számítottuk. A meteorológiai állomást 2006-ban szerelték fel, mi a 2006.01.01-jétől 2007.7.31-ig tartó intervallum adatait kaptuk meg és használtuk fel. A meteorológiai állomás 10 percenként mérte és naplózta az adatokat, ami a kiválasztott egy év esetén mintegy 48441 darab mérési adatnak felelt meg. A mérési adatok a felületi hőmérséklet mellett a környezeti hőmérsékletet, illetve adott mélységben jellemzően az egyes pályaszerkezeti rétegek középvonalában - 2, 7, 14, 29 és $49 \mathrm{~cm}$-en - mért hőmérsékleti adatokat tartalmazta.

Az 1. ábra a felületi hőmérséklet változását mutatja ezen egy év alatt. A magyar éghajlati viszonyok vonatkozásában az adatok viszonylag magas felületi-hőmérsékleteket mutatnak, ezt magyarázhatja az időjárási állomás körüli lokális éghajlati viszonyok, mivel az állomás egy aszfaltkeverőtelep sürün beépített, magas épületekkel leárnyékolt udvarán található. Az adatsor megszakadása a meteorológiai állomás két hétig tartó leállításának következménye, ezen időszakban az adatok gyüjtése elmaradt, ez azonban megítélésünk szerint elhanyagolható hatással van az éves hőmérsékleti eloszlásra. 


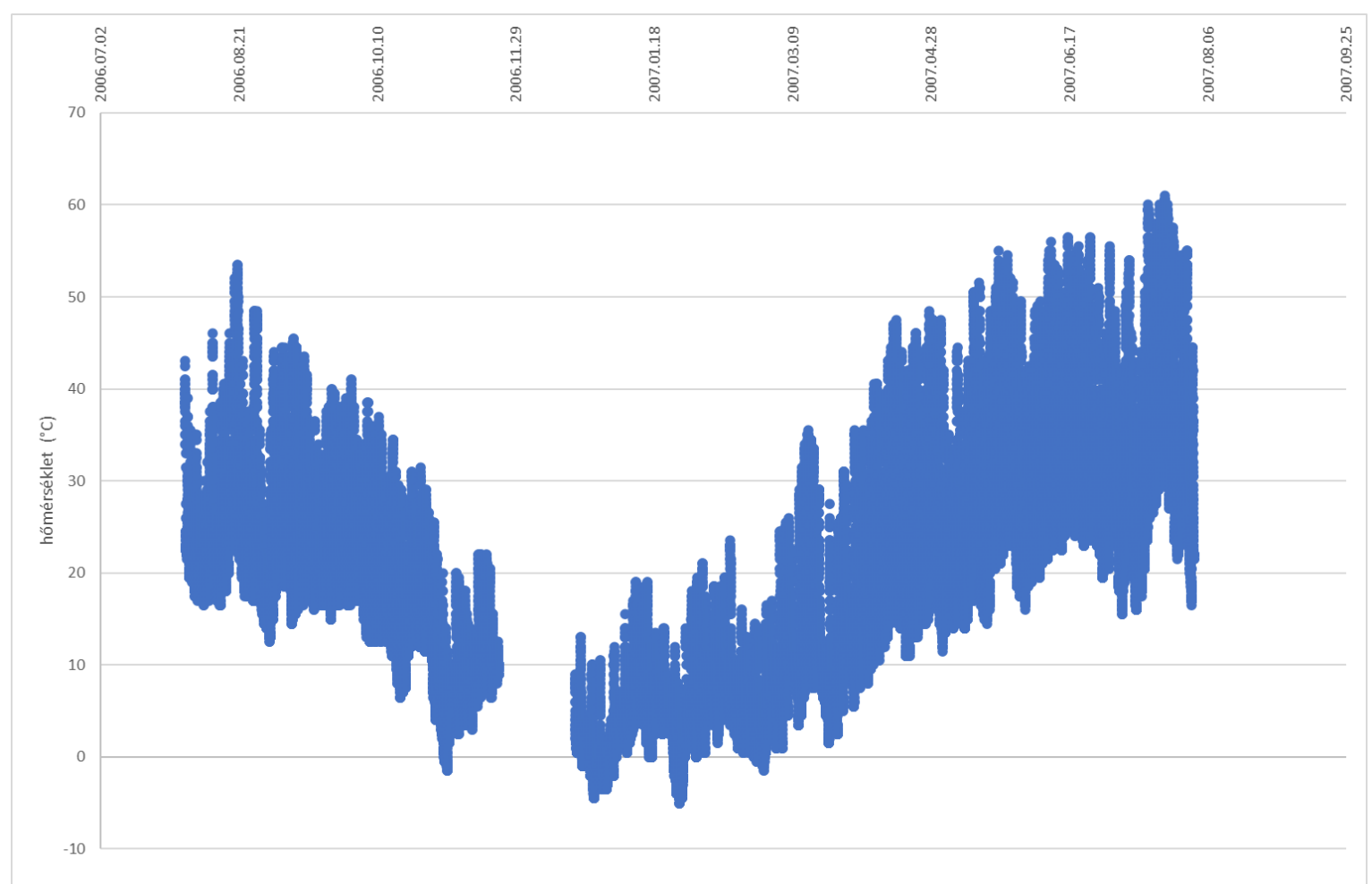

1. ábra: A felületi hőmérséklet változása egy év alatt.

A 2. ábrán látható hisztogram a $3{ }^{\circ} \mathrm{C}$ osztályközzel képzett, 22 darab hőmérsékleti osztály megoszlását mutatja.

a felületi hőmérséklet eloszlása

6000

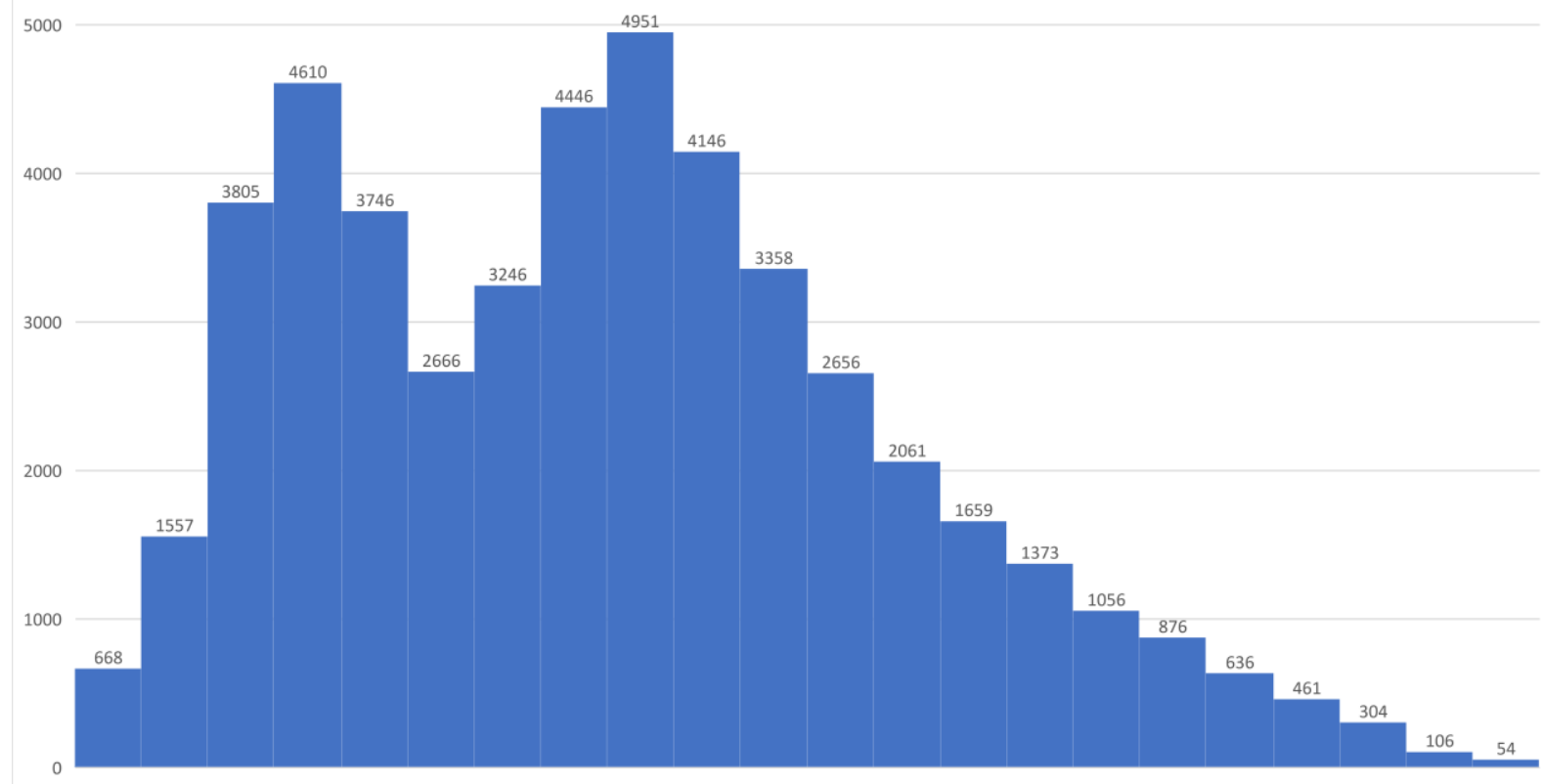

$[-5,-2] \quad(-2,1] \quad(1,4] \quad(4,7] \quad(7,10](10,13](13,16](16,19](19,22](22,25](25,28](28,31](31,34](34,37](37,40](40,43](43,46](46,49](49,52](52,55](55,58](58,61]$

2. ábra: Hőmérsékleti eloszlás hisztogramja. 
Az ábrából megállapítható például, hogy a leggyakrabban előforduló hőmérsékleti tartomány a 19$22{ }^{\circ} \mathrm{C}$ közötti tartományba esett. Elosztva ezen hömérsékleti intervallumba eső értékek elöfordulást az összes mért darabszámmal az alábbiak szerint:

$$
\frac{4951}{48441}=0,1022
$$

kapjuk, hogy a 19 és $22^{\circ} \mathrm{C}$ közötti hőmérsékleti tartományban az év 10,22 \%-ában fordult elő.

\section{AZ ASZFALTBURKOLATI RÉTEGEK HŐMÉRSÉKLETÉNEK BECSLÉSE}

Annak érdekében, hogy modellezni tudjuk a hőmérséklet lefutását a mélység függvényében a pályaszerkezetben, az elemzéshez egy $19 \mathrm{~cm}$ össz-aszfaltvastagságú, három aszfaltrétegböl álló szerkezetet modelleztünk az alábbiak szerint:

- $4 \mathrm{~cm}$ kopóréteg

- 6 cm-es kötőréteg

- $9 \mathrm{~cm}$-es aszfalt felső alapréteg.

Az egyes aszfaltrétegekben kialakuló hőmérsékletek becslésére az alábbi német módszert alkalmaztuk (Kayser, 2007; RDO, 2009). A módszer az 1. egyenlet szerint a felületi hőmérséklet ismeretében ad becslést az aszfaltrétegek tetszőleges mélységében ébredő hőmérsékleti viszonyokra.

$$
\mathrm{y}=\mathrm{a} \cdot \ln (0,01 \cdot \mathrm{x}+1)+\mathrm{T}
$$

ahol: „y” aszfalt becsült hőmérséklete $\left[{ }^{\circ} \mathrm{C}\right]$ „,x” mélységben, „, $[\mathrm{mm}]$, ,T” a felület hömérséklete $\left[{ }^{\circ} \mathrm{C}\right]$, ,a” paraméter a „T” függvényében (1. táblázat).

\begin{tabular}{|c|c|}
\hline Hőmérséklet & $\mathbf{a}$ \\
\hline$<-10$ & 6.5 \\
\hline$<-5$ & 4.5 \\
\hline$<0$ & 2.5 \\
\hline$<5$ & 0.7 \\
\hline$<10$ & 0.1 \\
\hline$<15$ & 0.3 \\
\hline$<20$ & 0.4 \\
\hline$<25$ & -1.6 \\
\hline$<30$ & -4.0 \\
\hline$<35$ & -6.2 \\
\hline$<40$ & -8.5 \\
\hline$<45$ & -10.5 \\
\hline$>45$ & -12.0 \\
\hline
\end{tabular}

1. táblázat: „a” paraméterek a felületi hőmérséklet függvényében.

A pályaszerkezeti rétegek hőmérsékletét elsőként a 2, 7 és $14 \mathrm{~cm}$ mélységben a fentiekben ismertetett német módszerrel becsültük és összevetettük a meteorológiai méröállomástól kapott, az azonos mélységben mért adatokkal. A becsült és a meteorológiai állomásról gyüjtött adatokat összevetve, megállapítottuk, hogy erős kapcsolat igazolható, mivel a korreláció szorosságát kifejező $\mathrm{R}^{2}$ értékek a következőképpen alakultak:

- 2 cm mélység: $\quad 0,98$

- 7 cm mélység: $\quad 0,89$

- 14 cm mélység: $\quad 0,79$ 
A 3. ábra a becsült hőmérsékletet mutatja a különféle mélységekben mért hőmérséklet függvényében.

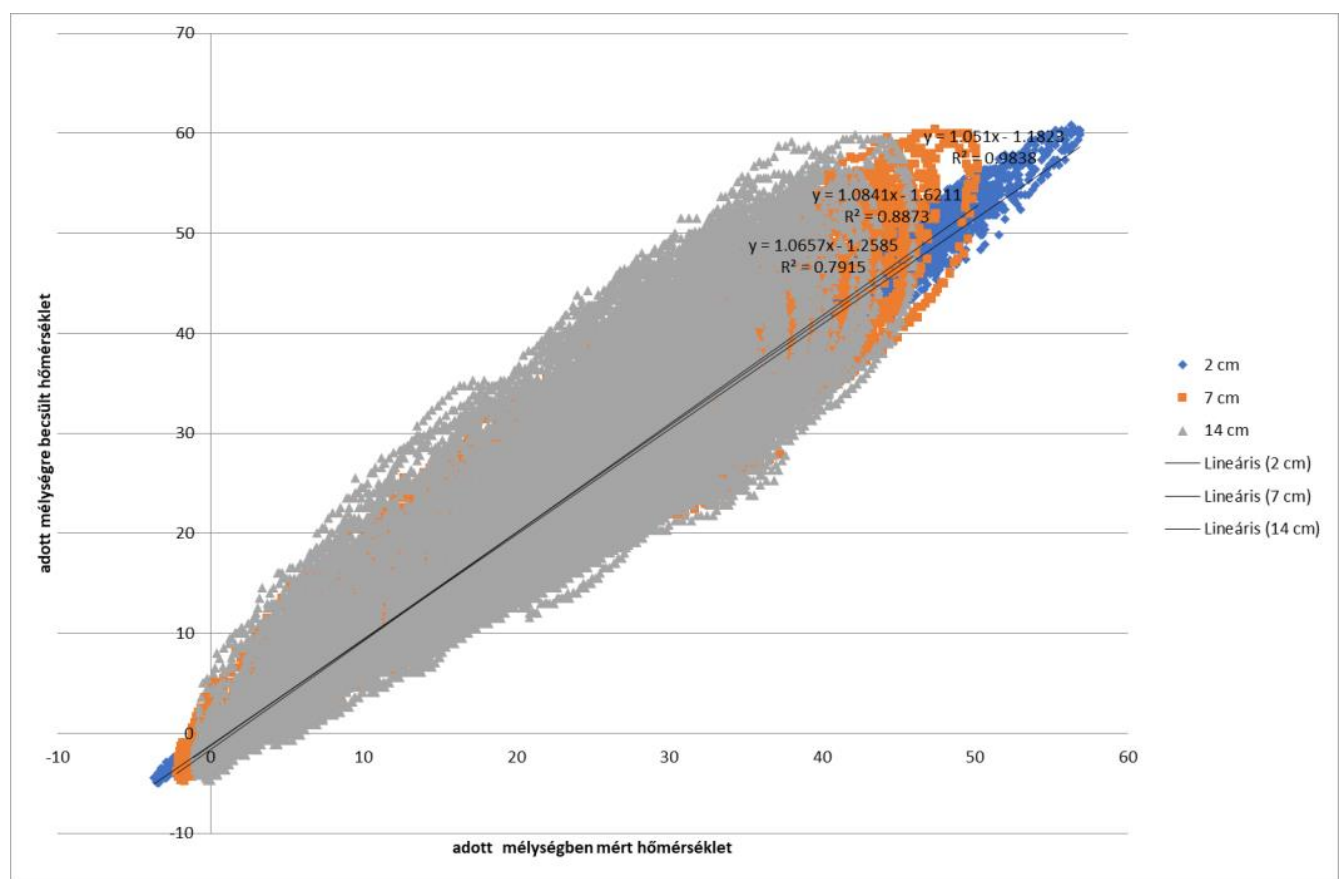

3. ábra: Becsült hőmérséklet a mért hőmérséklet függvényében.

A modellt tovább finomítva a teljes aszfaltvastagság 19 centiméterét 1 centiméteres, 19 különálló alrétegre bontottuk. Figyelembe véve továbbá, a felszíni hőmérséklet eloszlást 22 hőmérsékleti tartományra osztottuk, amint azt a fentiekben kifejtettük, a pályaszerkezet éves hőmérsékleti viszonyait megfelelő részletességgel a 2. táblázatban megadott 19x22-es mátrix írja le.

\begin{tabular}{|c|c|c|c|c|c|c|c|}
\hline $\begin{array}{l}\text { A pályaszerkezeti } \\
\text { modell sorszáma }\end{array}$ & 1 & 2 & 3 & $\ldots$ & 20 & 21 & 22 \\
\hline $\begin{array}{c}\text { a hömérsékleti } \\
\text { tartomány alsó határa } \\
\left({ }^{\circ} \mathrm{C}\right)\end{array}$ & -5 & -2 & 1 & $\ldots$ & 52 & 55 & 58 \\
\hline $\begin{array}{c}\text { a hömérsékleti } \\
\text { tartomány felső határa } \\
\left({ }^{\circ} \mathrm{C}\right)\end{array}$ & -2 & 1 & 4 & $\ldots$ & 55 & 58 & 61 \\
\hline $\begin{array}{c}\text { a hömérsékleti } \\
\text { tartomány átlagértéke } \\
\left({ }^{\circ} \mathrm{C}\right)\end{array}$ & $\begin{array}{l}- \\
3.5\end{array}$ & -0.5 & $\begin{array}{l}2, \\
5\end{array}$ & $\cdots$ & $\begin{array}{c}53 . \\
5\end{array}$ & $\begin{array}{c}56 . \\
5\end{array}$ & $\begin{array}{c}59 . \\
5\end{array}$ \\
\hline $10 \mathrm{~mm}$ & $\overline{-}$ & -0.3 & $\begin{array}{l}2 . \\
6\end{array}$ & $\cdots$ & $\begin{array}{c}52 . \\
4\end{array}$ & $\begin{array}{c}55 . \\
4\end{array}$ & $\begin{array}{c}58 . \\
4\end{array}$ \\
\hline $20 \mathrm{~mm}$ & $\begin{array}{l}- \\
3.0\end{array}$ & 0.0 & $\begin{array}{l}2 . \\
6\end{array}$ & $\cdots$ & $\begin{array}{c}51 . \\
3\end{array}$ & $\begin{array}{c}54 . \\
3\end{array}$ & $\begin{array}{c}57 . \\
3\end{array}$ \\
\hline $30 \mathrm{~mm}$ & 2.8 & 0.2 & $\begin{array}{l}2 . \\
7\end{array}$ & $\cdots$ & $\begin{array}{c}50 . \\
4\end{array}$ & $\begin{array}{c}53 . \\
4\end{array}$ & $\begin{array}{c}56 . \\
4\end{array}$ \\
\hline $40 \mathrm{~mm}$ & 2.7 & 0.3 & $\begin{array}{l}2 . \\
7\end{array}$ & $\cdots$ & $\begin{array}{c}49 . \\
5\end{array}$ & $\begin{array}{c}52 . \\
5\end{array}$ & $\begin{array}{c}55 . \\
5\end{array}$ \\
\hline $50 \mathrm{~mm}$ & 2.5 & 0.5 & $\begin{array}{l}2 . \\
8\end{array}$ & $\cdots$ & $\begin{array}{c}48 . \\
6\end{array}$ & $\begin{array}{c}51 . \\
6\end{array}$ & $\begin{array}{c}54 . \\
6\end{array}$ \\
\hline $60 \mathrm{~mm}$ & 2.3 & 0.7 & $\begin{array}{l}2 . \\
8\end{array}$ & $\cdots$ & $\begin{array}{c}47 . \\
9\end{array}$ & $\begin{array}{c}50 . \\
9\end{array}$ & $\begin{array}{c}53 . \\
9\end{array}$ \\
\hline $70 \mathrm{~mm}$ & 2.2 & 0.8 & $\begin{array}{l}2 . \\
9\end{array}$ & $\ldots$ & $\begin{array}{c}47 . \\
1\end{array}$ & $\begin{array}{c}50 . \\
1\end{array}$ & $\begin{array}{c}53 . \\
1\end{array}$ \\
\hline $80 \mathrm{~mm}$ & 2. & 1.0 & $\begin{array}{l}2 . \\
9\end{array}$ & $\ldots$ & $\begin{array}{c}46 . \\
4\end{array}$ & $\begin{array}{c}49 . \\
4\end{array}$ & $\begin{array}{c}52 . \\
4\end{array}$ \\
\hline $90 \mathrm{~mm}$ & $\overline{-}$ & 1.1 & $\begin{array}{l}2 . \\
9\end{array}$ & .. & $\begin{array}{c}45 . \\
8\end{array}$ & $\begin{array}{c}48 . \\
8\end{array}$ & $\begin{array}{c}51 . \\
8\end{array}$ \\
\hline $10 \mathrm{~mm}$ & $\begin{array}{c}- \\
1.8\end{array}$ & 1.2 & $\begin{array}{l}3 . \\
0\end{array}$ & $\cdots$ & $\begin{array}{c}45 . \\
2\end{array}$ & $\begin{array}{c}48 . \\
2\end{array}$ & $\begin{array}{c}51 . \\
2\end{array}$ \\
\hline
\end{tabular}




\begin{tabular}{|c|c|c|c|c|c|c|c|}
\hline $110 \mathrm{~mm}$ & $\begin{array}{c}- \\
1.6\end{array}$ & 1.4 & $\begin{array}{c}3 . \\
0\end{array}$ & $\cdots$ & $\begin{array}{c}44 . \\
6\end{array}$ & $\begin{array}{c}47 . \\
6\end{array}$ & $\begin{array}{c}50 . \\
6\end{array}$ \\
\hline $120 \mathrm{~mm}$ & $\begin{array}{c}- \\
1.5\end{array}$ & 1.5 & $\begin{array}{c}3 . \\
1\end{array}$ & $\cdots$ & $\begin{array}{c}44 . \\
0\end{array}$ & $\begin{array}{c}47 . \\
0\end{array}$ & $\begin{array}{c}50 . \\
0\end{array}$ \\
\hline $130 \mathrm{~mm}$ & $\begin{array}{c}- \\
1.4\end{array}$ & 1.6 & $\begin{array}{c}3 . \\
1\end{array}$ & $\cdots$ & $\begin{array}{c}43 . \\
5\end{array}$ & $\begin{array}{c}46 . \\
5\end{array}$ & $\begin{array}{c}49 . \\
5\end{array}$ \\
\hline $140 \mathrm{~mm}$ & $\begin{array}{c}- \\
1.3 \\
\end{array}$ & 1.7 & $\begin{array}{c}3 . \\
1\end{array}$ & $\cdots$ & $\begin{array}{c}43 . \\
0\end{array}$ & $\begin{array}{c}46 . \\
0\end{array}$ & $\begin{array}{c}49 . \\
0\end{array}$ \\
\hline $150 \mathrm{~mm}$ & $\begin{array}{c}- \\
1.2\end{array}$ & 1.8 & $\begin{array}{l}3 . \\
1\end{array}$ & $\cdots$ & $\begin{array}{c}42 . \\
5\end{array}$ & $\begin{array}{c}45 . \\
5\end{array}$ & $\begin{array}{c}48 . \\
5\end{array}$ \\
\hline $160 \mathrm{~mm}$ & $\begin{array}{c}- \\
1.1\end{array}$ & 1.9 & $\begin{array}{l}3 . \\
2\end{array}$ & $\cdots$ & $\begin{array}{c}42 . \\
0\end{array}$ & $\begin{array}{c}45 . \\
0\end{array}$ & $\begin{array}{c}48 . \\
0\end{array}$ \\
\hline $170 \mathrm{~mm}$ & $\begin{array}{c}- \\
1.0\end{array}$ & 2.0 & $\begin{array}{l}3 . \\
2\end{array}$ & $\cdots$ & $\begin{array}{c}41 . \\
6\end{array}$ & $\begin{array}{c}44 . \\
6\end{array}$ & $\begin{array}{c}47 . \\
6\end{array}$ \\
\hline $180 \mathrm{~mm}$ & $\begin{array}{c}- \\
0.9\end{array}$ & 2.1 & $\begin{array}{l}3 . \\
2\end{array}$ & $\cdots$ & $\begin{array}{c}41 . \\
1\end{array}$ & $\begin{array}{c}44 . \\
1\end{array}$ & $\begin{array}{r}47 . \\
1\end{array}$ \\
\hline $190 \mathrm{~mm}$ & $\begin{array}{c} \\
0.8\end{array}$ & 2.2 & $\begin{array}{l}3 . \\
2\end{array}$ & $\cdots$ & $\begin{array}{c}40 . \\
7\end{array}$ & $\begin{array}{c}43 . \\
7\end{array}$ & $\begin{array}{c}46 . \\
7\end{array}$ \\
\hline
\end{tabular}

2. táblázat: A 19*22-es mátrix szemléltetése.

\section{A KÖTŐANYAG ÉS AZ ASZFALTKEVERÉK PARAMÉTEREINEK MEGHATÁROZÁSA A HŐMÉRSÉKLET FÜGGVÉNYÉBEN}

A számításokhoz a kötőanyag tulajdonságait úgy tekintettük, hogy azok PG 64 -22 fokozatnak felelnek meg. A PG (Performance Graded) jelölés a bitumen viselkedése fokozatára utal, a két számérték pedig a környezeti feltételeket leíró magas, illetve alacsony burkolattervezési hőmérsékleteket jelenti. Ebben az esetben egy PG 64-22 fokozatú kötőanyag a szabványban foglalt elöírásokat $64{ }^{\circ} \mathrm{C}$-nál kisebb, átlagos 7 napos magas burkolathömérsékletre és $-22{ }^{\circ} \mathrm{C}$-nál nagyobb, alacsonyabb éves átlagú burkolathőmérsékletre vonatkozóan elégíti ki.

A bitumen hömérsékletfüggő viszkozitás értékeit a 2 és 3 egyenletekkel határoztuk meg (NCHRP, 2011).

$$
\begin{aligned}
& \log \log (\eta)=A+\operatorname{VTSlog}\left(T_{R}\right), \text { ha } T_{R}>T_{\text {kritikus }} \\
& \log \log (\eta)=1095, \text { ha } T_{R}<=T_{\text {kritikus }}
\end{aligned}
$$

Ahol, „П” viszkozitás [cP], „TR” hőmérséklet [Rankine]. A PG 64-22 minőségü kötőanyagokra az alábbi paraméterek vonatkoznak:

$\mathrm{A}=-3680$ és VTS $=10980$.

A részletes modellezéshez a különböző aszfaltrétegeket a kopó, kötő és alaprétegbe építhető keverékekre jellemző összetételekre vonatkozó - eltérő - paraméterekkel vettük figyelembe. Ezen paramétereket a 3. táblázat foglalja össze, ahol a paraméterek a dél-koreai követelmények alapján lettek megadva (Molit, 2015) azonban hazai elöírásokkal is jellemzően összhangban vannak.

\begin{tabular}{|c|c|c|c|c|c|c|c|}
\hline Rétegek & $\mathbf{p}_{\mathbf{3 4}}$ & $\mathbf{p}_{\mathbf{3 8}}$ & $\mathbf{p}_{\mathbf{4}}$ & $\mathbf{p}_{\mathbf{2 0 0}}$ & $\mathbf{\mathbf { V } _ { \mathbf { a } }}$ & $\mathbf{\mathbf { V } _ { \text { beff } }}$ & $\mathbf{f} \mathbf{( H z )}$ \\
\hline kopóréteg & 0 & 38,75 & 72,5 & 10 & 3,08 & 12,2 & 25 \\
\hline kötőréteg & 2,5 & 24 & 45 & 6 & 4,159 & 10,5 & 25 \\
\hline alapréteg & 13 & 35 & 51 & 4 & 3,777 & 9,3 & 25 \\
\hline
\end{tabular}

3. táblázat: A különböző aszfaltrétegek modellezéséhez felhasznált paraméterek.

Tekintve a 2. táblázat első oszlopát, amely a (-5) és $(-2){ }^{\circ} \mathrm{C}$ felületi hőmérsékleti tartományra, $(-3,5)$ ${ }^{\circ} \mathrm{C}$ középérték figyelembevételével az 1 . egyenlet alapján, centiméterenként tartalmazza a becsült hőmérsékleti értékeket, amelyek bemeneti paramétereket biztosítanak a kötőanyag dinamikus viszkozitásának előrejelzésére, amelyet a 2 és 3 egyenlet szerint számíthatunk ki. 
A kötőanyag viszkozitásának ismeretében pedig becsülhető a keverék merevsége az alábbi (4) egyenlet segítségével. Ez az összefüggés az úgynevezett Witczak-egyenlet, amellyel meg lehet becsülni az aszfaltréteg modulusát a kötőanyag dinamikus viszkozitásának és az aszfaltkeverék tulajdonságainak függvényében (MOLIT, 2015).

$$
\begin{aligned}
& \log \left|E^{*}\right|=6.940166-0.00176\left(P_{200}\right)+0.003889\left(P_{4}\right)-0.08776\left(V_{a}\right)-1.33426 \frac{V_{\text {eff }}}{V_{\text {eff }}+V_{a}}+ \\
& \frac{\left(-3.63992-0.03114\left(P_{4}\right)+0.015546\left(P_{38}\right)+0.010469\left(P_{34}\right)\right)}{1+\exp (-0.09942+0.162727 \times \log f+0.180695 \times \log \eta)}
\end{aligned}
$$

\begin{tabular}{|c|c|c|c|}
\hline $\begin{array}{l}\text { Pályaszerkezeti } \\
\text { rétegek }\end{array}$ & $\begin{array}{l}\text { Mélység } \\
(\mathrm{mm})\end{array}$ & $\begin{array}{c}\text { Kötőanyag dinamikai } \\
\text { viszkozitása ( } 10^{6} \text { Poise) }\end{array}$ & $\begin{array}{c}\text { Aszfaltmodulus } \\
(\mathrm{MPa})\end{array}$ \\
\hline \multirow{4}{*}{ kopóréteg } & 10 & 25820 & 23,211 \\
\hline & 20 & 23725 & 22,832 \\
\hline & 30 & 21955 & 22,489 \\
\hline & 40 & 20438 & 22,176 \\
\hline \multirow{6}{*}{ kötőréteg } & 50 & 19125 & 27,784 \\
\hline & 60 & 17976 & 27,489 \\
\hline & 70 & 16963 & 27,215 \\
\hline & 80 & 16062 & 26,959 \\
\hline & 90 & 15255 & 26,719 \\
\hline & 100 & 14529 & 26,494 \\
\hline \multirow{9}{*}{ alapréteg } & 110 & 13872 & 32,697 \\
\hline & 120 & 13275 & 32,452 \\
\hline & 130 & 12729 & 32,220 \\
\hline & 140 & 12228 & 31,999 \\
\hline & 150 & 11768 & 31,789 \\
\hline & 160 & 11342 & 31,589 \\
\hline & 170 & 10947 & 31,398 \\
\hline & 180 & 10581 & 31,214 \\
\hline & 190 & 10239 & 31,039 \\
\hline
\end{tabular}

A számítást példaként a (-5) - (-2) ${ }^{\circ} \mathrm{C}$ hőmérsékleti tartományra az alábbiakban közöljük, ahol az aszfaltréteg-modulust a 4. táblázatban foglaltak szerint számítottuk.

4. táblázat: Anyagparaméterek becsült értékei $\left(T=-3.5^{\circ} \mathrm{C}\right)$.

Hasonló módon a számítások a további 21 hőmérsékleti tartományra elvégezhetőek, és ebben az esetben előállítható az egyéves időszak hőmérsékleti viszonyait lefedő, azt kellőképpen reprezentáló 22 pályaszerkezeti modell aszfaltrétegekre vonatkozó része.

\section{A VÉGESELEM MODELLEK ELEMZÉSE}

Annak érdekében, hogy a teljes pályaszerkezet viselkedését modellezni tudjuk, az eddig vizsgált aszfaltrétegek alá, amelyeket 19 darab $1 \mathrm{~cm}$ vastag aszfalt al-réteggel jellemeztünk, $20 \mathrm{~cm}$ vastag, 350 MPa modulusú, nem kötött szemcsés alapréteget és $50 \mathrm{MPa}$ altalaj teherbírást tételeztünk fel.

Az így már teljes pályaszerkezetet az (NCHRP/TRB, 2004) ajánlása alapján 9m x 9m x 9m, köbös VEM modellé alakítottuk, biztosítva, hogy a vízszintes alsó és függőleges oldalsó peremek ne közelítsék meg a terhelő felület középpontját az ajánlott 50, illetve 12 keréksugárnál jobban. Feltételeztük, hogy a szokványos $50 \mathrm{kN}$-os kerékterhelés egyenletesen oszlik meg egy kör alakú, $15 \mathrm{~cm}$ sugarú felületen. Az aszfalt, az alapréteg és az altalaj anyagára 2,3, 2,0 és 1,5 t/ $\mathrm{m}^{3}$ önsúlyterhet alkalmazunk, ebben a sorrendben. A végeselem-modellben a tartomány negyedét vettük figyelembe, és szimmetrikus 
peremfeltételeket alkalmaztunk a szimmetria felületeire, míg az alsó réteg legalsó pontjait függőleges elmozdulásokkal, az egész tartományt merevtestszerü elmozdulásokkal szemben megtámasztottuk. A végeselem modellben nyolc csomópontú 3D szerkezeti szilárd testelemeket alkalmaztunk (az ANSYS szoftverben SOLID185 elemtípus), minden csomóponton három szabadságfokkal. A 19. aszfalt alréteg a szemcsés alaphoz, valamint a szemcsés alap az altalajhoz súrlódásmentes kontakt elemekkel kapcsolódtak.

A vízszintes fajlagos nyúlásokat az aszfaltrétegek alján (4. ábra) és a függőleges elmozdulást a földmű tetején kiszámítottuk (5. ábra).

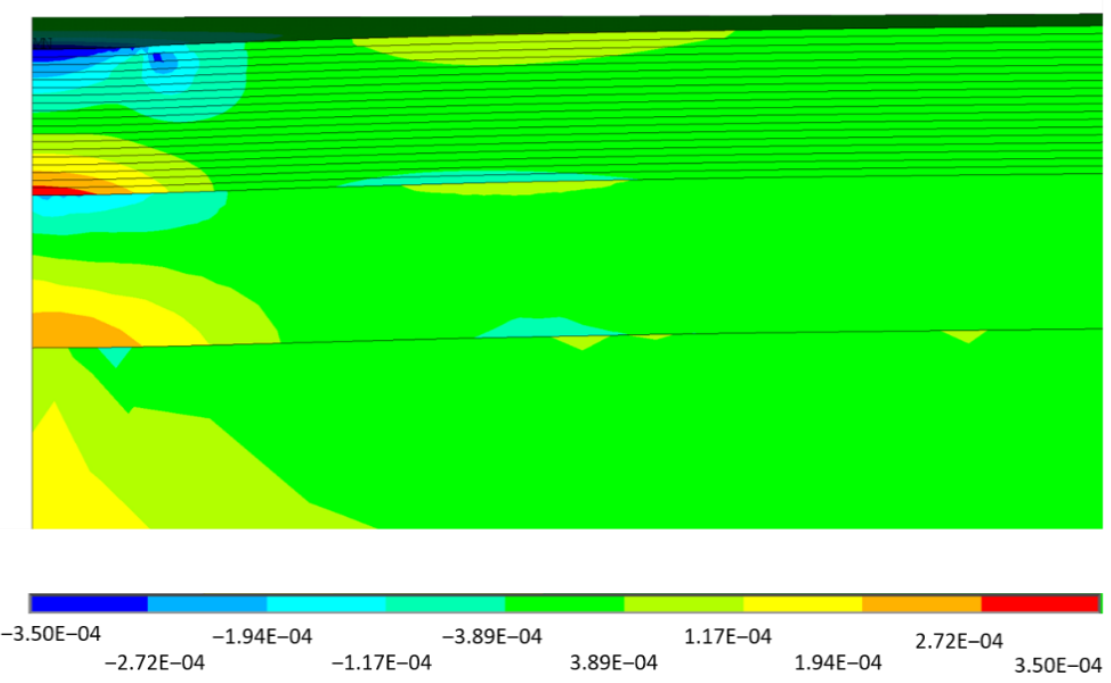

4. ábra: A vízszintes megnyúlások [-] alakulásának szemléltetése a 22. számú modellben
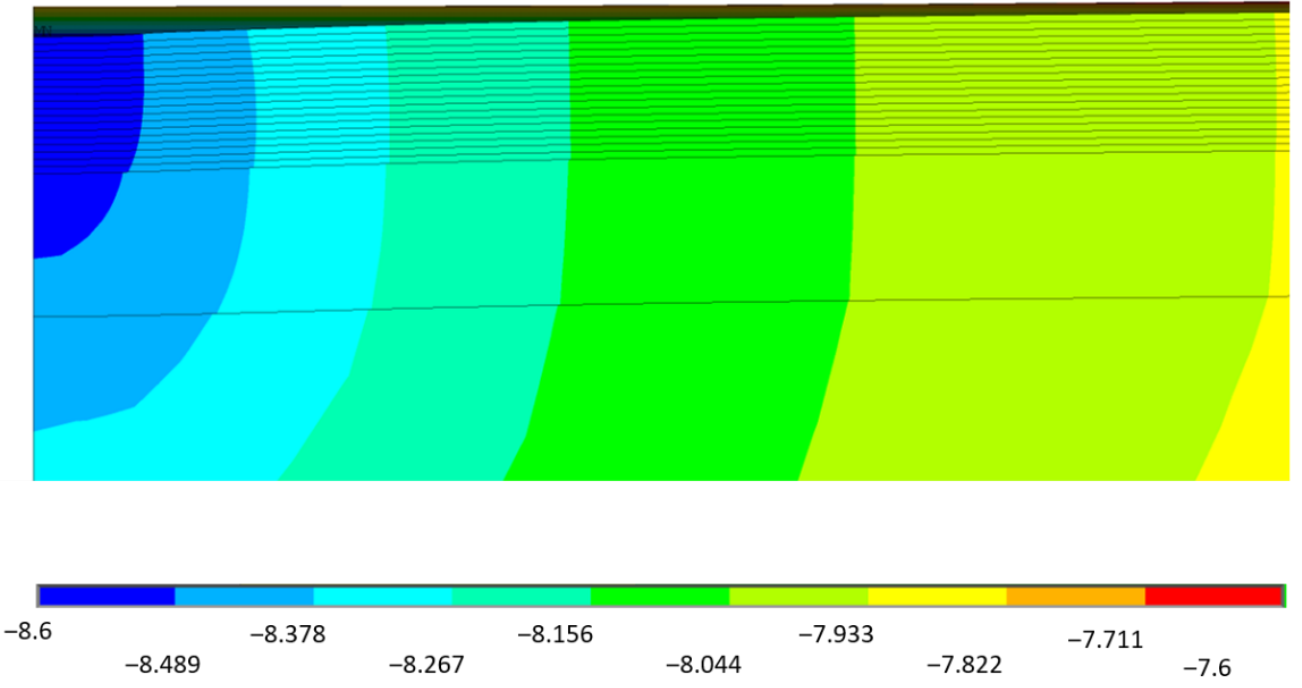

5. ábra: A függőleges eltolódások [mm] szemléltetése a 22. számú modellben

Mind a 22 pályaszerkezeti modellre végeselemes számítás segítségével kiszámított igénybevételeket a 7. táblázat foglalja össze.

\section{A PÁLYASZERKEZET KUMULATÍV FÁRADÁSA}

Annak érdekében, hogy a vizsgált pályaszerkezet viselkedését modellezni tudjuk, tételezzük fel, hogy a várható forgalmi terhelés 1 millió egységtengely, amely évközben egyenletesen oszlik el. Azaz a 22 darab pályaszerkezeti modellre a forgalmi terhelés megoszlása megegyezik a felületi hőmérséklet eloszlással, amint azt az 5. táblázat mutatja. 


\begin{tabular}{|c|c|c|c|}
\hline $\begin{array}{l}\text { A hőmérsékleti } \\
\text { osztály } \\
\text { sorszáma (1-22) }\end{array}$ & $\begin{array}{c}\text { Mért } \\
\text { hőmérsékleti } \\
\text { adatok } \\
\text { száma (-) }\end{array}$ & $\begin{array}{c}\text { Adott } \\
\text { hőmérséklet } \\
\text { gyakorisága } \\
(\%)\end{array}$ & $\begin{array}{c}\text { Tényleges } \\
\text { tervezési } \\
\text { forgalom } \\
\text { (Ni, tényleges) }\end{array}$ \\
\hline 1 & 668 & 1,38 & 13790 \\
\hline 2 & 1557 & 3,21 & 32142 \\
\hline 3 & 3805 & 7,85 & 78549 \\
\hline 4 & 4610 & 9,52 & 95167 \\
\hline 5 & 3746 & 7,73 & 77331 \\
\hline 6 & 2666 & 5,50 & 55036 \\
\hline 7 & 3246 & 6,70 & 67009 \\
\hline 8 & 4446 & 9,18 & 91782 \\
\hline 9 & 4951 & 10,22 & 102207 \\
\hline 10 & 4146 & 8,56 & 85589 \\
\hline 11 & 3358 & 6,93 & 69321 \\
\hline 12 & 2656 & 5,48 & 54830 \\
\hline 13 & 2061 & 4,25 & 42547 \\
\hline 14 & 1659 & 3,42 & 34248 \\
\hline 15 & 1373 & 2,83 & 28344 \\
\hline 16 & 1056 & 2,18 & 21800 \\
\hline 17 & 876 & 1,81 & 18084 \\
\hline 18 & 636 & 1,31 & 13129 \\
\hline 19 & 461 & 0,95 & 9517 \\
\hline 20 & 304 & 0,63 & 6276 \\
\hline 21 & 106 & 0,22 & 2188 \\
\hline 22 & 54 & 0,11 & 1115 \\
\hline Total & 48441 & 100,00 & $\begin{array}{c}1000000 \\
\text { egységtengely }\end{array}$ \\
\hline
\end{tabular}

5. táblázat: A hőmérsékleti értékek gyakorisága alapján a forgalmi terhelés megoszlása.

A megengedett forgalmi terhelést a Shell által kidolgozott alapösszefüggés ausztrál változatával (Austroads Ltd., 2017.), az alábbi összefüggéssel határozható meg:

$$
N=\frac{S F}{R F}\left[\frac{6918\left(0.856 V_{b}+1.08\right.}{E^{0.36} \mu \epsilon}\right]^{5}
$$

ahol: „N" a megengedett teherismétlődések száma, „, $\mu$ ” megengedett megnyúlás aszfalt felsőalapréteg alsó síkján (microstrain), „, $\mathrm{V}_{\mathrm{b}}$ ” bitumen térfogat\%-a az aszfaltrétegben [\%], „E” aszfalt modulus [MPa], „SF” eltolási tényező a laboratóriumi és az üzem fáradtsági élettartamok között (feltételezett érték =6), „RF” megbízhatósági tényező (6. táblázat).

\begin{tabular}{|c|c|c|c|c|c|}
\hline \multicolumn{7}{|c|}{ Megbízhatóság } \\
\hline $50 \%$ & $80 \%$ & $85 \%$ & $90 \%$ & $95 \%$ & $97.5 \%$ \\
\hline 1.0 & 2.4 & 3.0 & 3.9 & 6.0 & 9.0 \\
\hline
\end{tabular}

A (5) egyenlet segítségével az VEM modellszámítások eredményeként kapott aszfaltmegnyúlások felhasználva, mind a 22 pályaszerkezeti modell esetén meghatározható a megengedett tengelyterhelés értéke, amelyet a 7. táblázat tartalmaz. 


\begin{tabular}{|c|c|c|}
\hline $\begin{array}{l}\text { Pályaszerkezeti } \\
\text { modell sorszáma } \\
\quad(1-22)\end{array}$ & $\begin{array}{l}\text { Becsült vízszintes } \\
\text { megnyúlás } \\
\text { (microstrain) } \\
\text { (ANSYS) }\end{array}$ & $\begin{array}{c}\text { Megengedett forgalmi terhelés } \\
\text { (Ni, engedett) a (4) egyenlet } \\
\text { szerint }\end{array}$ \\
\hline 1 & 48 & $30,039,423$ \\
\hline 2 & 56 & $20,120,211$ \\
\hline 3 & 60 & $15,579,040$ \\
\hline 4 & 68 & $10,986,355$ \\
\hline 5 & 79 & $7,431,197$ \\
\hline 6 & 91 & $4,999,914$ \\
\hline 7 & 105 & $3,460,413$ \\
\hline 8 & 120 & $2,412,376$ \\
\hline 9 & 127 & $1,974,324$ \\
\hline 10 & 143 & $1,422,479$ \\
\hline 11 & 149 & $1,216,528$ \\
\hline 12 & 167 & 899,067 \\
\hline 13 & 174 & 771,340 \\
\hline 14 & 181 & 670,285 \\
\hline 15 & 201 & 512,766 \\
\hline 16 & 210 & 444,640 \\
\hline 17 & 231 & 348,753 \\
\hline 18 & 244 & 299,301 \\
\hline 19 & 267 & 240,659 \\
\hline 20 & 290 & 196,196 \\
\hline 21 & 314 & 162,043 \\
\hline 22 & 339 & 135,481 \\
\hline
\end{tabular}

7. táblázat: A VEM modell segítségével megkapott megnyúlások az alsó aszfaltréteg alsó síkjában és az ez alapján becsült megengedett forgalmi terhelés értékek

Ezen értékeket (7. táblázat, utolsó oszlop) összevetve a feltételezett forgalmi terheléssel (5. táblázat utolsó oszlop) minden egyes pályaszerkezeti modell esetére meghatározható a kumulált fáradás mértéke, ahol 0: a terheletlen szerkezet és 1: a kifáradt szerkezetet szimbolizáló szélsőérték. A kumulatív károsodási tényezőt (CDF) a Miner hipotézissel (6. egyenlet) számítottuk:

$$
\mathrm{CD}=\sum_{\text {MINER }}=\frac{\mathrm{N}_{1, \text { tényleges }}}{\mathrm{N}_{1, \text { megeng }}}+\frac{\mathrm{N}_{2, \text { tényleges }}}{\mathrm{N}_{2, \text { megeng }}}+\frac{\mathrm{N}_{3, \text { tényleges }}}{\mathrm{N}_{3, \text { megeng }}}+\ldots \frac{\mathrm{N}_{22, \text { tényleges }}}{\mathrm{N}_{22, \text { megeng }}} \leq 1
$$

ahol: „N $\mathrm{i}$ i,tényleges” ( $\mathrm{i}=1 \ldots 22)$, a forgalmi terhelés tényleges száma „i” pályaszerkezeti modellnél, „N $\mathrm{N}_{\mathrm{i}, \mathrm{megeng}}$ ( $\left.\mathrm{i}=1 \ldots 22\right)$, megengedett tengelyterhelés , ii” pályaszerkezeti modellre.

1 millió egységtengely és 95\% -os megbízhatósági szint mellett a CDF-érték 0,72; következésképpen a pályaszerkezet mintegy $28 \%$-os szerkezeti kapacitással (fáradási tartalékkal) rendelkezik. Abban az esetben, ha a forgalmi terhelést 1,34 millióra növeljük, a CDF-értéket 0,99-re emelkedik és megközelíti az elméleti határát, azaz a vizsgált pályaszerkezet ennél magasabb fáradási igénybevételt nem képes elméletileg elviselni.

\section{A KAPOTT EREDMÉNYEK ÖSSZEVETÉSE REFERENCIASZERKEZETTEL}

Annak érdekében, hogy a VEM modellel kapott eredményeket értékelni tudjuk, az így kapott eredményeket egy ún. hagyományos, 5 rétegü modellszámítás eredményeivel vetettük össze, ahol a hőmérséklet hatását az ún. ekvivalens hőmérsékleten keresztül vettük figyelembe. Ebben a számításban egyetlen pályaszerkezeti modellt hoztunk létre. 
$\mathrm{Az}$ ekvivalens hőmérséklet számítását ebben a cikkben nem tárgyaljuk, értékére $20{ }^{\circ} \mathrm{C}$-ot állapítottunk meg (Gribovszki et al., 2016) és ehhez a hőmérsékleti értékhez tartozó modulus értékekkel számoltunk, a 8. táblázatban foglaltakkal összhangban.

\begin{tabular}{|c|c|}
\hline Pályaszerkezeti rétegek & Modulus (MPa) \\
\hline $4 \mathrm{~cm}$ aszfalt kopóréteg & 4,000 \\
\hline $6 \mathrm{~cm}$ aszfalt kötőréteg & 5,800 \\
\hline $9 \mathrm{~cm}$ aszfalt alapréteg & 4,500 \\
\hline $20 \mathrm{~cm}$ szemcsés alapréteg & 350 \\
\hline altalaj & 50 \\
\hline
\end{tabular}

8. táblázat: Referencia pályaszerkezeti modell.

A számításokat Shell BISAR programmal elvégezve az aszfaltrétegek alsó síkjában kiszámított vízszintes nyúlás 143 (mikronyúlás vagy microstrain) adódott, amelyhez 4250836 egységtengely terhelés tartozik 95\% -os megbízhatósági szint mellett.

A két megközelítés közötti különbség jól látható és számszerüsíthető. A hőmérsékleti hatások részletesebb figyelembevétele jelentősen csökkentette az elméletileg meghatározható megengedett forgalmi terhelést.

\section{7. ÖsSZEFOGLALÁS}

Az aszfaltrétegekre gyakorolt hőmérsékleti hatás figyelembevétele döntő tényező a pályaszerkezet méretezésénél. Ebben a cikkben az alsóbb aszfaltrétegek hőmérsékletét a német irányelvek alapján becsültük meg. A becsült értékek megfelelő összefüggésben voltak a korábban létre hozott meteorológiai állomásról gyüjtött valós adatokkal, és jó korrelációt kaptunk. Ezt a lépést követően meghatároztuk a hőmérséklet-eloszlás relatív gyakoriságát.

A pályaszerkezetünk aszfaltrétegeinek modelljét 19 darab $1 \mathrm{~cm}$ vastag rétegekböl építettük fel, annak érdekében, hogy megfelelően tükrözze a hömérséklet-változást, amit pedig a kötőanyag viszkozitásának és az aszfalt modulusának becsléséhez használtunk fel.

Az így elvégzett modellszámítások és az ún. ekvivalens (egyenértékü) hőmérsékleti módszerrel végzett egyszerüsített számítások összehasonlítása azt mutatta, hogy a cikkben vázolt részletes modell jobb előrejelzést nyújthat a pályaszerkezet valós, teljes szerkezeti kapacitásáról. Ennek oka az, hogy a hagyományos módszer nem tudja figyelembe venni az aszfaltburkolat szerkezetére gyakorolt hőmérsékleti hatások komplexitását.

A módszer rávilágít arra, hogy a részletes hőmérsékleti profil alkalmazásával végzett számítás valósághübb bemenetet nyújt a szerkezet kialakításához, és realisztikusan mérlegelhető a különféle aszfaltkeverékek, polimerrel vagy gumival modifikált keverékek, ill. ún. nagy modulusú aszfaltkeverékek közötti teljesítményeltérések hatása.

\section{HivatKozÁs}

Austroads. 2017: Guide to Pavement Technology Part 2: Pavement Structural Design, Sydney: Austroads Ltd.

Gribovszki, Z., Igazvölgyi, Z., Kalicz, P., Pethő, L., Kisfaludi, B., Tóth, C., Markó, G., Soós, Z., Péterfalvi, J., Szentpéteri, I. Primusz, P., Tódor, D. 2016: Alternatív méretezési eljárásokra vonatkozó tanulmány és az alternatív módszerek bevezetését segítő irányelv. Kutatási jelentés. Megrendelő: Közlekedésfejlesztési Koordinációs Központ.

Kayser, S. 2007: Berücksichtigung klimatischer Bedingungen bei der rechnerischen Dimensionierung von Oberbauten für Verkehrs-flächen, Dissertation, TU Dresden.

MOLIT. 2015: Mechanistic-empirical pavement design specification, Seoul: Ministry of Land, Infrastructure and Transport, Korea .

NCHRP. 2011: LTPP Computed Parameter: Dynamic modulus, US Department of Transportation Federal Highway Administration. 
Pethő, L. 2008: A hőmérséklet eloszlás alakulása az aszfalt burkolatú útpályaszerkezetekben és ennek hatása a pályaszerkezeti rétegek fáradási méretezésére, technológiai tervezésére. $\mathrm{PhD}$ értekezés.

RDO. 2009. Guidelines for mathematical dimensioning of foundations of traffic surfaces with a course asphalt surface, Research society for roads and traffic, Berlin. 